\title{
Investment Intensity of International Return-Migrant: A Case Study of East Java - Indonesia International Migration
} Khusnul Ashar ${ }^{1, *}$ Bella Arum Kristanti ${ }^{2}$

\author{
${ }^{1,2}$ Brawijaya University \\ ${ }^{*}$ Corresponding author: khusnul_ashar@yahoo.co.id
}

\begin{abstract}
Working abroad is an alternative strategy to change the quality of life by the poor family. Working as migrant workers is an alternative for some people to change their lives. After a long time of migration, many migrant workers return to their regions and they do not have a sustainable income again. The presence of migrant workers or returning Indonesian migrant workers (TKI) has actually led to problems which have become quite serious problems in the labor sector. These problems mostly led to a culture of hedonism and consumerism so Ex-Indonesian migrant workers do not have sustainable income. There is a tendency where migrant workers do not have the commitment to create sustainable business units that can create income after becoming migrant workers and even lead to unemployment. Whereas, investments must be made after returning from abroad. It has been occurring in Tulungagung Regency which is one of the main areas of the Indonesian Migrant Workers. As it has been stated in some theories that factors influencing investment decisions are the amount of income, individual and family characteristics, psychological factors, and external factors such as knowledge or skills. Therefore, this study aims to find out the reasons of ex-migrant workers' investment decision by involving several factors that were quantitative method and tested by using binary logistic regression models. The sample of this research are 42 Ex-Indonesian migrant workers. The results show that the factors that have significant influences are income, other wealth, marital status, number of family liabilities, education, length of work, and government training. Then, this research also proves that the investment determinants of ex-migrant workers in Tulungagung Regency are not only themselves but also their families.
\end{abstract}

Keywords: Investment Intensity, Return-Migrant, Underlying Factors

\section{INTRODUCTION}

This template, Ease of Use Many countries have problems concerning employment including Indonesia. It must be admitted that Indonesia has job vacancies proportions that are not comparable to the workforce or job seekers proportions, thereby it is triggering unemployment and leading international migration [1] Besides, an international migration is done to obtain a higher income. Profits from overseas workers are leading to a much higher level of income and welfare [2]. So, working as an Indonesian Migrant Worker (TKI) becomes a trend to increase income and to overcome unemployment. However, based on the data of Agency for the Placement and Protection of Indonesian Migrant Workers (Badan Nasional Penempatan dan Perlindungan Tenaga Kerja/BNP2TKI), there was a decrease in the number of migrant workers from 2011 to 2018 with an average percentage decrease by $28 \%$ each year. This indicates that many ex-migrant workers have returned to their regions.

Then, related to TKI, Tulungagung Regency is one of the 20 largest regions contributing migrant workers according to BNP2TKI. The area that has a large number of migrant workers in Indonesia, at East Java Province, Indonesia also experienced a decrease in the number of migrant workers. The number of migrant workers from Tulungagung Regency decrease with an average of 25 percent annually. The sharp decrease had happened from 2011 to 2018, from 9,273 people becoming 2,863 people. The existence of Indonesian migrant workers who have returned can trigger several problems that become quite serious problems in the employment sector, in which due to the hedonism and consumerism culture, former migrant workers do not have sustainable income [3]. Likewise, there is a tendency where the ex-migrant workers do not commit to create sustainable 
business units that can give income after becoming migrant worker so it even leads to unemployment cases.

Many cases show that after becoming migrant workers, they become helpless people again such as losing assets, and even returning to work abroad because these migrant workers do not make investments, such as saving or accumulating assets. As it has been happening in several regions in Indonesia, ex-migrant workers in Gresik district tend not to have a sustainable income after they do not become migrant workers [4]. Former migrant workers in Sukabumi Regency have very small investment intensity and a higher level of consumption which causes many social problems that occur in migrant workers' households. Social impacts occur when the migrant worker goes abroad such as the social impact that occurs to the children of migrant workers who are left behind. Many issues such as lack of attention happen to children who was left by their parent which worked as migrant workers. Furthermore, in some cases, a divorce often occurs to the families of migrant workers.

Whereas, the migration is done to change and to improve material conditions and not to cause social problems [5]. This is partly because they are not able to allocate their income ideally [6]. Most of the remittances are still used to pay repayment loan, then it is used for domestic consumptions. About 8 percent are used for education and only 6 percent are used for investment purposes or opening a business. Adams and Cuecuecha [7] state that the remittances are mostly used for consumption than investment. BNP2TKI states that migrant workers should work abroad only as a safety valve because they do not obtain decent works yet in the country. Therefore, it is expected that after returning from abroad (ex-migrant workers), or migrant workers will work in their own country or become entrepreneurs that can emerge various productive businesses and create jobs opportunity, because they are the owners of larger assets that guarantee their families and regions. Ideally, the results from abroad are for the investment of sustainable livelihoods. The results obtained by migrant workers that have already returned can improve the conditions of migrants and their families and further create a better orientation through investments in the education, health, and economy [4]. The employment sector is indeed a sector that becomes the most concerns in the context of poverty alleviation.

Several previous studies discussed a lot about migrant workers and the welfare of families that receive migrant money. Overseas workers significantly increase opportunities for poor households to escape from poverty [8]. Pajaron [9] say that migration has a positive impact on the economic conditions of migrant families who receive money in the village. Mondal and Khanam [10] say that if foreign remittances are invested by migrants, it might significantly contribute to household welfare. Adams and Cuecuecha [7]find that there was a decrease in the Gini index when remittance became one of the capitals for households in Indonesia. The impact of investment from working abroad is very significant for the next life. Jimenez - Soto and
Brown [11] find that national poverty rates can be reduced by remittance and by good management. The kinds of utilization of income from overseas according to Dustmann and Kirchkamp Lee [2] are including basic consumption, long-term investment, and investment in increasing the capacity and skills of the family (capacity building).

For migrant workers who have returned to their regions or homeland (ex-migrant workers), investment should be made to improve the standard of living and sustainable economic development in the country, they are prosperous not only when they are abroad, but also when they are in their regions by using the income and various skills as an investment, but in fact there are still many ex-migrant workers who do not make investments. According to the Association of Ex-Indonesian Migrant Workers in Tulungagung, there are still many migrant workers who do not make productive investments. With a ratio around $40 \%$ of the total migrant workers who have returned, they do not make investments yet or in this case they do not carry out productive economic activities. It is unknown yet what caused the ex-migrant workers prefer making investment to allocating remittances for consumption. In reality, the role of investment for a region's income is multiplier or it can be said as having a multiplier effect. If all ex-migrant workers can save money and use remittances for productive activities or spend their money to increase ownership of capital goods, then, in the future they can maintain the economic stability of their families.

Along with the fact that there is a decrease in the number of Indonesian migrant workers and the importance and magnitude of the ex-migrant workers' potential in developing their origin areas, this research is very necessary to complete the literature about ex-migrant workers in Indonesia with the investment intensity approach. The purpose of this study is to find out what causes the exmigrant workers choose to make investment and what causes the ex-migrant workers do not choose to make investments.

Using primary data from 42 former migrant workers in Tulungagung, East Java, it is estimated with binary logistic regression. This paper consists of six parts: First is introduction. The literature review of relevant theories will be on section two, then section three will explain the research method used in this paper. The results of the research will be discussed in section four. Result implications will be on section five and the last, concluding remarks will be stated on chapter six.

\section{LITERATURE REVIEW}

The literature review section will consist of two major parts: the theory of migration and the theory of investment as explained below.

\subsection{Migration}

Migration can be interpreted as a change of a residence [12]. Lee [12] mentioned that population mobility is generally caused by differences between two regions including the 
factors in the origin and the factors in the destination area. This theory is called Push and Pull Theory.

Migration also occurs in the movement of population to cross national borders called International Migration. According to Mulyadi [13], international migrations that occur in developing countries are basically caused by economic differences between countries. International migrations are generally carried out by family members to do a cross-border or international work and to overcome poverty [9].

In the post-migration stage, migrant workers who have returned can be said as a consequence of an international migration because their return is enough to provide a challenge for the employment of various countries and to redevelop skills and wealth from abroad including how they should utilize their income after returning to their regions and create changes that lead to better things in the society [4].

Post-migration workers or referred to Former Migrant Workers is every migrant worker who has returned to Indonesia (homeland) either because his contract has ended or because of other reasons. The main concentration addressed to the former migrant workers is their ability to manage the income that they receive from their work abroad. The expectation of former migrant workers is that they can be wise in managing their finances to provide welfare for their families.

\subsection{Investment}

Post-migration workers or referred to Former Migrant Workers is every migrant worker who has returned to Indonesia (homeland) either because his contract has ended or because of other reasons. The main concentration addressed to the former migrant workers is their ability to manage the income that they receive from their work abroad. The expectation of former migrant workers is that they can be wise in managing their finances to provide welfare for their families.

According to Haming [14], investment is investment for one or more assets that owned with the hope of getting profits in the future. Investment is a sacrifice made at the present time to get greater benefits in the future.

There are several investments that can be chosen, such as (1) Real Asset Investment and Financial Asset Investment, where real assets are assets that have an intrinsic worth due to its substances and physical properties. The examples of real assets are land, houses, gold, and other precious metals. Then (2) Human Capital Investment, this investment is to sacrifice something that can be measured by the value of money with the hope of being able to obtain a better income in the future [15] such as investment in education and health. Then, (3) business investment, investment for business (to earn income) is the expenditure investments of companies to purchase capital goods and production equipment that increases the ability to produce goods and services and can absorb workers.

According to Xiao et al. [16], some factors that are very important and affect investments are demographic factors, including age, educational level, marital status, and race. Then, there are the financial source factors, such as income and wealth. In addition, psychological Factors, it is the expectations of economic conditions and motivation. Ultimately, other factors are also mentioned by Hao et al. [17] including gender, age, marital status and duration of stay abroad correlated with investment decisions, and also relevant policies encouraged by the government to invest.

However, when migrant workers return to their place of origin, they must make investment. A study conducted in Sri Lanka shows that the post-migration will have a significant role in the ownership of assets (including vehicles and land) in the place of origin of migrants. Migrants' families that have more agricultural land tend to use remittances for the purpose of investment. This investment activity is largely influenced by income and characteristics of migrants. Meanwhile, families that still have school-age children tend to use it for educational purposes. This proves that remittances are not only used for consumption purposes but also for investment.

The topics of this research are mostly about labors and migrations. There are several previous researches dealing with labors and migrations. The first is a research conducted by [8]. He states that by being migrant workers, people will enable to increase income rapidly and increase their investment in education, real estate (property), and medical care in which migrant workers turn out to get very much profits with a much higher level of welfare. Then, [5] also explains that the variable of the capital affects the income of ex-migrant workers or former migrant workers (TKI Purna) in North Sumatra so that their welfare also increases. Furthermore, a research conducted by Hamidah [15] shows that making investments has an impact on sustainable livelihoods in the family.

All of the studies mentioned above state that the income of migrant workers will have a positive impact on the family. The age and education factors influence the development of the potential of Full-time Migrant Workers for becoming entrepreneurs. Démurger and $\mathrm{Xu}$ [18] explains that the return of migrants is more likely to become entrepreneurs influenced by individual, family, and regional characteristics. Then, in Turkey, there are some factors that influence saving behavior carried out by the family including age, sex, educational level, and the numbers of the family. Likewise, Basu and Rajan [19] shows that the investment spending, households, and individual characteristics influence investment behavior, where investments made mostly by former migrant workers are educational investments. However, Kristanti et al. [20] conducted a research that is contrary to this research. They say that the knowledge variable has no effect on investment decisions.

\section{METHODS}

This study uses quantitative research approach, in which is used to examine a particular population or sample. Data collection technique was done by using survey to 42 migrants. Totally there were 73 ex-migrant workers from Rejotangan sub-district and respondents were chosen by using the Slovin 
formula. The research location was selected by employing purposive sampling technique. The researcher determined Tulungagung Regency, East Java Province, Indonesia as the research location because it is one of the largest places of migrant workers throughout the history until now. Tulungagung Regency is one of the 20 largest regions contributing TKI. Then the researcher chose Rejotangan District because this area is a rural area in Tulungagung Regency with highest number of migrant workers where this area is directly adjacent to other cities or regencies. Furthermore, data analysis used is binary logistic regression methods. The logistic regression model used in this research is as follows.

$\operatorname{Dec}(\mathrm{Yi})=\ln (\mathrm{Pi} / 1-\mathrm{Pi})=\beta 0+\beta 1 \mathrm{X} 1+\beta 2 \mathrm{X} 2+\beta 3 \mathrm{D} 3+$ $\mathrm{B} 4 \mathrm{X} 4+\mathrm{B} 5 \mathrm{D} 5+\mathrm{B} 6 \mathrm{D} 6+\mathrm{B} 7 \mathrm{X} 7+\mathrm{B} 8 \mathrm{X} 8+\mathrm{B} 9 \mathrm{X} 9+\mathrm{B} 10$ $\mathrm{D} 10+\mathrm{u} 1(1)$

The dependent variable, Yi is the response of ex-migrant workers in making investment decisions, $\mathrm{Y}=1$ if respondents choose to invest, and $\mathrm{Y}=0$ if respondents choose not to make investment.

Independent variables, there are 10 variables in this study, namely Income (X1); Other Wealth, 1 if respondents have other wealth such as land, rice fields, inheritance or livestock, 0 if they do not have other wealth (X2); Gender, 1 for men, and 0 for women (D3); Age (X4); Marital Status, number 1 for respondents who have married, number 0 for those who are unmarried or for those who have divorced (D5); Confidence, number 1 if the respondents state that they have confidence for making investments and number 0 if the respondents state that they do not have confidence for investing and they choose not to invest (D6); Number of Family Liabilities (X7); Education, count by year of schooling (D8). Elementary School $=6$ years; Middle school $=9$ years; High School = 12 years; Non-degree diploma qualification $(\mathrm{D} 1 / \mathrm{D} 3)=15$ years; Bachelor Degree $(\mathrm{S} 1)=$ 16 years; Length of Work (X9); and the last Government training (X10), number 1 if the respondent joined training held by the government, and number 0 if the respondent did not join training held by the government.

Some tests that has been done in this logistic regression analysis are assessing the fit model by using the Hosmer and Leme show test, then it was continued by using the -2 LogLikelihood Statistics test to determine if independent variables are added to the model whether or not it significantly improves the fit model. Then, Cox and Snell's R Square is a measure that tries to imitate the size of $\mathrm{R} 2$ in multiple regressions based on likelihood techniques with a maximum value of less than one that is difficult to interpret [21].

With the steps of implementing the research and development strategy carried out is First, research and data collection (research and information collecting) which includes literature studies and research on a small scale. Second, arrange planning (planning). Next, put forward several research hypotheses. Many things affect the choice of investment decisions. Based on an overview of investment it is said that aspects of income, social aspects, demographic aspects, aspects of education, aspects of experience have a role in making decisions both in allocating income or can be called investment [15].

\section{RESULTS AND DISCUSSIONS}

This study uses quantitative research approach, in which is used to examine a particular population or sample. Data collection technique was done by using survey to 42 migrants. Totally there were 73 ex-migrant workers from

The results of research and sampling showed that there were 26 people (former migrant workers) who chose investment and 16 people (former migrant workers) who did not choose investment or chose to do more consumption.

The result of testing the hypothesis using Hosmer and Lemeshow Test reached Sig value of 0.053 where this is bigger than alpha 5\%. This means that the model is good. Furthermore, the test results showed that the decrease value of -2 Log- Likelihood at BLOCK 0 was 58.224 and BLOCK 1 was 18.630 . These results indicate that the hypothesized model is fit with the data. Then, the result of test of Cox \& Snell and Nagelkerke R-Square showed that independent variables in the study were able to explain respondents' investment of $81.4 \%$ while the remains of $18.6 \%$ were explained by other variables outside the research model.

Furthermore, the researcher also analyzed the data by using Test Significance of the Parameters or Wald test. This test was conducted to determine the relationship of the variables examined in this study. In this study, a logistic regression test was carried out on the factors that had a strong influence on the investment intensity of ex-migrant workers in Rejotangan District, Tulungagung Regency, and East Java Province, Indonesia. The estimation results showed that Income (X1), Other Wealth (X2), Marital Status (D5), Number of Family Liabilities (X6), Education (X8), Length of Work (X9), Government Training (D10) affected the investment intensity of ex-migrant workers. Meanwhile, Gender (D3), Age (X4), Confidence (D7) did not affect the investment intensity of ex-migrant workers. The following table shows the results of the Binary Logistic regression test.

Table 1. Regression Test Results Of Binary Logistic.

\begin{tabular}{|c|c|c|c|c|c|}
\hline Variables & $\mathrm{B}$ & $\mathrm{SE}$ & Wald & Sig. & $\begin{array}{c}\text { Exp } \\
(\mathrm{B})\end{array}$ \\
\hline Income & -.295 & .694 & .181 & $.031^{*}$ & .744 \\
\hline $\begin{array}{c}\text { Other } \\
\text { Wealth }\end{array}$ & -2.838 & 2.311 & 1.509 & $.021^{*}$ & .059 \\
\hline Gender & -1.977 & 1.588 & 1.550 & .213 & .138 \\
\hline Age & .213 & .192 & 1.231 & .267 & 1.237 \\
\hline $\begin{array}{c}\text { Marital } \\
\text { Status }\end{array}$ & -2.303 & 2.179 & 1.117 & $.011^{*}$ & .100 \\
\hline $\begin{array}{c}\text { Family } \\
\text { Liabilities }\end{array}$ & -.360 & 1.174 & .094 & $.029^{*}$ & .698 \\
\hline
\end{tabular}




\begin{tabular}{|c|c|c|c|c|c|}
\hline Variables & $\mathrm{B}$ & SE & Wald & Sig. & $\begin{array}{c}\text { Exp } \\
\text { (B) }\end{array}$ \\
\hline $\begin{array}{c}\text { Confidenc } \\
\mathrm{e}\end{array}$ & $\begin{array}{c}- \\
21.021\end{array}$ & $\begin{array}{c}17072.8 \\
70\end{array}$ & .000 & .999 & .000 \\
\hline Education & $-4,378$ & 2,711 & 2.872 & $.038^{*}$ & \\
\hline $\begin{array}{c}\text { length of } \\
\text { Work }\end{array}$ & -.058 & .317 & .033 & $.04^{\star}$ & .944 \\
\hline $\begin{array}{c}\text { Gov. } \\
\text { Training }\end{array}$ & -3.987 & 1.732 & 5.300 & $.021^{*}$ & .019 \\
\hline Constant & 2.319 & 5.962 & .151 & .697 & 10.170 \\
\hline
\end{tabular}

*significant in $95 \%$ degree of confidence

From the results above, it is known that the significance value of the income factor 0.031 is less than the significance level of $5 \%(0.05)$, which means that the income factors influence the investment decision of the ex- migrant workers, with a negative coefficient. This shows that ex-migrant workers who have high incomes are not making investments. While ex-migrant workers with low incomes tend to make investments. According to [22], there is a point in which exmigrant workers with high income do not know about investment, so they are inclined to consume rather than to invest. These results are consistent with an investment potential survey of Indonesian migrant workers conducted by BNP2TKI that proves that the higher income of ex-migrant workers (above IDR 5,000,000,-) the smaller the percentage of interest in making investments. This is related to social class which is related to the level of consumption.

Other wealth factors have a significance value of 0.021 which means that they have a significant effect on the exmigrant workers' investment decision making behavior, with a negative coefficient. This finding proves that when exmigrant workers do not have other wealth, they tend to invest. Otherwise, ex-migrant workers who have other wealth such as agricultural land or livestock and even inheritance tend not to invest. This relates to the ex-migrant workers' willingness in maximizing their income for investment. The researcher saw those ex-migrant workers who had no other wealth were more motivated to invest because they did not have other wealth that would sustain their next life. But wealth in the form of agricultural land or livestock and even the inherited land has a high sale value, so this triggers an interest in deciding investment by migrant workers.

The gender factor has a significance value of 0.213 which means that it does not affect the labors' investment decision. [6] mention that gender has no effect on financial planning and investment. Gender equality that equalizes the rights of men and women in making investments, because managing business investment or other investments can be controlled not only by men but also by women. So, investment decision making behavior is not significantly influenced by gender.

In this study, the age factor has a significance value of 0.267 . It indicates that age has no significant effect on the investment decision of ex-migrant workers. Both young and old are not included as the determinants of investment decision making behavior, because investment can be planned in various age ranges. Planning for investments in various age ranges is necessary because the financial goals at each age are different. People will be able to obtain optimal returns throughout the age range. Many investment choices can be chosen by ex-migrant workers such as investment assets that include land or rice fields and buildings. Then, currently, banks have created various kinds of investments such as bonds, savings or stock interest, and choices of business investment. Various kinds of investment can be made by people of all ages. In a result, ex-migrant workers can choose the best investment based on their financial goals that they want to achieve.

From the estimation results, it is known that the marital status variable has a significance value of 0.011 which means that it influences the investment decision of the ex-migrant workers. Basu and Rajan [19] say that marital status also influences the decision to invest. From the interpretation of the direction of the coefficient, it is obtained negative results, which means that ex-migrant workers with marital status have a tendency not to invest, while ex-migrant workers with unmarried status tend to invest. In the interconnection between marriage and investment, the two factors are related to each other because this is related to the future financial preparation and the fulfillment of family needs. For exmigrant workers who are unmarried, investment decisions after returning from abroad is an opportunity to arrange their finances for the sake of sustainable life.

The number of family liabilities factor has a significance value of 0.029 which means that it influences the decision investment of the ex-migrant workers. The direction of the coefficient shows negative result. This means that ex-migrant workers with a small number of family liabilities tend to make investment. While ex-migrant workers who have a large number of family liabilities tend not to make investment. More family members equal to more needs that must be fulfilled, and there is a high consumption pattern while the tendency for investment is low. According to [2], in a family, the number of family members largely determines the number of family needs. The more family members mean a lot of family needs that must be fulfilled. Otherwise, the fewer family members mean the fewer needs that must be fulfilled and the tendency of investment is high because there is little consumption.

From the estimation results, also known that the significance value of the confidence factor is 0.999 , which means that confidence does not significantly influence the investment decision of the ex-migrant workers. However, for the ex-migrant workers, the family becomes a consideration for investment decisions, not only for "himself". Although the ex-migrant worker feels confident about his decision, the family condition becomes his consideration to allocate more money for investment or consumption. So the confidence does not affect investment decisions. It is also explained in the Household Decision Theory namely the Collective Model approach. This model assumes that the husband and wife in a 
household have different preferences and or bargaining power. In this model, the household is seen as a place for interaction or bargaining between individual members. Decisions taken by households reflect the results of a negotiation and strategic behavior among members.

Education has a significance value of 0.038 which means it significantly affect the investment decision of ex-migrant workers. Dustmann and Kirchkamp [2] assert that education influences ex-migrants to engage in entrepreneurial activities. Basu and Rajan [19] also mention that the education influences the investment of migrants' families. Meanwhile, the coefficient shows a negative sign. This means that workers with higher education tend not to invest. Otherwise, workers with lower education tend to invest. Education is related to income. Ex-migrant workers with low education are in occupational positions such as laborers that have low remittances. However, ex-migrant workers with low-income were very able to control their consumption and they were able to make to investment whatever the amount of income presentation allocated.

It is known that the factor of the length of the work has a significant effect that reach the value of 0.046 . This result is in line with Basu and Rajan [19] that the length of time migrant workers work abroad influences the investment behavior. Then, this result shows a negative coefficient, which means that the longer they work, the more they do not make investment. The findings explain that there was a mistake in allocating income when workers were working abroad, so when they returned to their regions, they did not have the income to invest.

The test results show a significance value of 0.021 that government training factors significantly influence the investment decision of ex-migrant workers. The coefficient shows a negative value which means that ex-migrant workers who attended government training tend not to invest. Indeed, those who did not attend the government training decide to invest. This shows that training has not been optimal for affecting investment decisions for ex-migrant workers.

The pattern of utilization and investment varies from one family to another. From the sample of 26 people who chose an investment, $46 \%$ chose investment in the business sector. Furthermore, $23 \%$ were making investments in property, such as houses, land, and rice fields. Then, around $11 \%$ worker chose to save money in order to earn interest and deposit their money in the banks or similar financial institutions. While around $12 \%$ chose to invest in education, by sending their children to school. They expected to improve human resources and their children welfare in the future. The remain is $8 \%$ of respondents that chose to invest in jewelry or gold and gems. This investment is favored by many ex-migrant workers because it can be used and jewelry or gold and gems values also never dropped. The data also revealed the fact that no respondents were investing in stocks or foreign currencies. This condition is certainly very rational, considering their location or presence in the region and the environmental effect which will influence their decisions to choose the type of investments.
Furthermore, 16 respondents who did not choose to invest, almost $47 \%$ of respondents used money from their overseas income for consumption or their daily needs. Meanwhile the rest of the respondents used money for other needs. $13 \%$ of respondents chose to use their income to buy assets that tend dropping in value. Then, around $33 \%$ used the money to buy a vehicle which is only a "lifestyle" and around $7 \%$ spent their money paying debts without thinking about investment.

\section{RESEARCH IMPLICATION}

The migrant workers and their families can use the income from abroad for consumption that can support a better health, property investment, and a better educational investment, as well as can build small businesses. Besides, productive investment is also needed as well as independent entrepreneurs who are able to reduce the rate of unemployment. If this affects the family or micro level, remittances will also affect the macro level. A better program formation is needed to encourage ex-migrant workers to invest. The Government can thoroughly invite and encourage ex-migrant workers even in remote areas. The existence of the Government in the operational level will ensure the enforcement of provisions in paying better attention to migrant workers after returning to the regions generally and especially for those who are in rural areas. If it is necessary, national banks can collaborate with BNP2TKI in improving financial, entrepreneurship education, and trainings for exmigrant workers. Besides, ex-migrant workers who already have had businesses are expected to be facilitated with credit and business assistance. The government needs a new approach in managing former migrant workers in the future. This must be conducted so that ex-migrant workers do not come back to abroad. In addition, they must be encouraged to contribute actively on the domestic economy.

\section{CONCLUSION}

According to the results of the research, the researcher concludes and gives several proposed arguments. First, dominant factors influencing the investment decisions of exmigrant workers in Rejotangan Sub-District, Tulungagung Regency, are income factors, other wealth, marital status, number of family liabilities, education, length of work, and government training. While the factors of age, gender, and confidence do not have a significant influence on the investment decisions of ex-migrant workers from Rejotangan sub-district, Tulungagung Regency.

Second, the investment determinants of ex-migrant workers from Rejotangan Sub-district, Tulungagung Regency, choose to invest are mostly because of the family characteristics and structure. All considerations are due to the support of the family, not merely themselves who determine investment decisions.

Moreover, migrant workers must be supported not only with knowledge and skills but also education about financial problems, including for families at home. Family is the main 
user of remittance money from migrant workers. There were some cases in which remittance money was not used properly, so migrant workers did not have money when returning home. It would be better embedding a mindset to start making investments such as opening business or being an entrepreneur, so migrant workers can support their daily needs and even it can become new livelihoods after returning from abroad.

Thus, the role of the regional government is very needed, such as the Labor Affairs and Social Affairs Agency can collaborate to create various programs for ex-migrant workers or former migrant workers. The problem of poverty, unemployment, and low knowledge will be difficult to be solved, if the knowledge and skills are only possessed by migrant workers or ex-migrants workers and the family. Good policies need to be developed to reach and help exmigrant workers in the rural areas also..

\section{REFERENCES}

[1] R. Wirastyani, S. Kanto, H. M. Siahaan, Migrasi Internasional dan Pemanfaatan Remitansi Dalam Rangka Pengentasan Kemiskinan (Kasus di Desa Clumprit Kecamatan Pagelaran Kabupaten Malang), WACANA, J. Sos. dan Hum., vol. 19(3), 2016.

[2] C. Dustmann, O. Kirchkamp, The optimal migration duration and activity choice after re-migration, J. Dev. Econ., vol. 67(2), 2002, pp. 351-372.

[3] Bank Indonesia., National survey results of migrant worker remittance pattern. Bank Indonesia, 2008.

[4] M. Rafique Wassan, Z. Hussain, M. Ali Shah, S. N. Amin, International labor migration and social change in rural Sindh, Pakistan, Asian Pacific Migr. J., vol. 26(3), 2017, pp. 381-402.

[5] T. Supriana, V. L. Nasution, Peran usaha TKI purna terhadap pengembangan ekonomi lokal dan faktor yang mempengaruhi pendapatan usaha TKI purna di Provinsi Sumatera Utara, J. Makara Sos. Hum., vol. 14(1), 2010, pp. 42-50.

[6] R. K. Brahmana, R. K. M. R. Brahmana, The Financial Planning and Financial Literacy of ex-Malaysia Indonesian Migrant Workers. Petra Christian University, 2017.

[7] R. H. J. Adams, A. Cuecuecha, The economic impact of international remittances on poverty and household consumption and investment in Indonesia. The World Bank, 2010.

[8] G. Ducanes, The welfare impact of overseas migration on Philippine households: Analysis using panel data, Asian Pacific Migr. J., vol. 24(1), 2015, pp. 79-106.
[9] M. C. Pajaron, The role of remittances as a risk-coping mechanism: Evidence from agricultural households in rural Philippines, Asian Pacific Migr. J., vol. 26(1), 2017, pp. 3-30.

[10] R. K. Mondal, R. Khanam, The impacts of international migrants' remittances on household consumption volatility in developing countries, Econ. Anal. Policy, vol. 59, 2018, pp. 171-187.

[11] E. V. Jimenez - Soto, R. P. C. Brown, Assessing the poverty impacts of migrants' remittances using propensity score matching: The case of Tonga, Econ. Rec., vol. 88(282), 2012, pp. 425-439.

[12] E. S. Lee, A theory of migration, Demography, vol. 3(1), 1966, pp. 47-57.

[13] S. Mulyadi, Human Resource Economics. jakarta: PT Raja Grafindo Persada., 2003.

[14] S. Haming, Murdifin Basamalah, Project and Business Feasibility Study. jakarta: Bumi Aksara, 2010.

[15] C. Hamidah, Dampak Remitansi Tenaga Kerja Indonesia (TKI) Luar Negeri Pada Peningkatan Investasi Daerah Asal, Ekuilibrium J. Ilm. Bid. Ilmu Ekon., vol. 8(1), 2016, pp. 1-14.

[16] J. J. Xiao, B. Sorhaindo, E. T. Garman, Financial behaviours of consumers in credit counselling, Int. J. Consum. Stud., vol. 30(2), 2006, pp. 108-121.

[17] X. Hao, K. Yan, S. Guo, M. Wang, Chinese returnees' motivation, post-return status and impact of return: A systematic review, Asian Pacific Migr. J., vol. 26(1), 2017, pp. 143-157.

[18] S. Démurger, H. Xu, Return migrants: The rise of new entrepreneurs in rural China, World Dev., vol. 39(10), 2011, pp. 1847-1861.

[19] B. Basu, I. Rajan, Investment Expenditure Behavior of Remittance Receiving Households: An Analysis Using Reserve Bank of India Data, Migr. Lett., vol. 15(3), 2018, pp. 303-320.

[20] B. A. Kristanti, K. Ashar, S. Muljaningsih, IDENTIFICATION OF FACTORS AFFECTING INVESTMENT INTENSITY BY EX-INDONESIAN MIGRANT WORKERS.

[21] I. Ghozali, Multivariate Analysis Application with SPSS Program, 4th ed. semarang: Diponegoro University, 2009. 